\title{
TRADISI MUNGGAH MOLO DI PEKALONGAN
}

Oleh :

MIFTAHUL ULA

\begin{abstract}
This study will attempt to uncover the tradition of munggah molo in Pekalongan to explore its forms of language; meanings embodied in symbols of munggah molo tradition; and the relationship between the function symbols in munggah molo tradition with social values and religious in Pekalongan.

This study uses anthropology of linguistic approach looking through the prism of the core concepts of anthropology, culture, and look for the hidden meaning behind the use or misuse of language in different forms, namely registers and style.

In the tradition of munggah molo performed by the Java community in Pekalongan are forms of language in the form of a special lexicon commonly used in munggah molo tradition. Likewise, in this tradition contain the symbolic languages that contain the values of life like munggah, molo, blandar, uwat-uwat, bengking, Gendero, kembang setaman (flower setaman), banan Sepet, basin, money nickels, canticles, coconut, umbrellas, golden spikes, rays, juwadah pasar, and so forth.

The symbols contained in molo munggah tradition means and intent that is hope. These symbolic meanings in some ways, a myth or public trust Pekalongan in understanding life. It occurs in hereditary and implemented to date in spite of the shift even a change in the procession and implementation.

The tradition of munggah molo in Pekalongan has a very important social function, especially in establishing social harmony in the society of Pekalongan. This harmony is not only applied for the Java community alone, but also the impact of this harmony can also be perceived by others as Chinese and Arabic ethnic.
\end{abstract}

Keywords : Ubo rampe, symbols, culture, social function. 


\section{Pendahuluan}

Bagi masyarakat Jawa pada umumnya, simbolisasi atau perlambang dalam sistem tata kehidupan manusia seperti sudah menjadi bagian tak terpisahkan. Ia sudah menjadi kebudayaan dan sistem nilai dalam kehidupan masyarakat. Kebudayaan yang menurut Ruth Benedict bermakna pola-pola pemikiran serta tindakan tertentu yang terungkap dalam aktifitas, sehingga pada hakekatnya kebudayaan itu adalah way of life, cara hidup tertentu yang memancarkan identitas tertentu pula pada suatu bangsa. Sedangkan menurut Koentjaraningrat, kebudayaan adalah keseluruhan sistem gagasan, tindakan dan hasil karya manusia dalam rangka kehidupan masyarakat yang dijadikan milik diri manusia dengan belajar.(Koentjaraningrat, 1986:180).

Salah satu wujud peninggalan kebudayaan adalah upacara tradisional, di masyarakat manapun termasuk jawa selalu terdapat upacara-upacara adat atau tradisi tertentu yang dilakukan. Upacara yang dimaksud adalah suatu kegiatan yang dimaksudkan untuk memperingati suatu peristiwa atau momen tertentu. Dan di dalam upacara tersebut selalu terlihat penggunaan simbol-simbol untuk mengungkapkan rasa budayanya. Simbol memiliki peranan yang penting dalam sebuah upacara, ia bisa berfungsi sebagai alat penghubung antar sesama manusia juga bisa befungsi sebagai penghubung antar manusia dengan benda dan antar dunia nyata dengan dunia gaib.(Purwadi, 2005: 126)

Karena itu simbol-simbol sebagai perlengkapan upacara, yang diwujudkan dalam bentuk sesaji merupakan bagian yang tak terpisahkan dari sebuah tradisi upacara. Karena itu kesalahan atau kekurangan perlengkapan ini akan mengakibatkan kurang sahnya atau kurang afdlalnya upacara, karena akan mengakibatkankan maksud dan tujuan penyelenggaraan upacara tidak tercapai. Sebagai makhluk spiritual, manusia selalu berusaha mencari jalan untuk berhubungan dengan alam "yang lain". Karenanya sesaji yang diberikan itu adalah media yang mengandung arti bahwa manusia sebenarnya ingin berkomunikasi dengan Tuhan, Dewa atau makhluk halus penghuni alam gaib lainnya. .(Purwadi, 2005: 103) 
Dalam kajian antropologi pola pikir yang dipengaruhi oleh pandangan akan adanya sesuatu kekuatan yang tidak tampak tadi disebut mitos. Mitos di sini diartikan sebagai sesuatu yang memberikan arah pada kelakuan manusia dan merupakan semacam pedoman untuk menentukan kebijaksanaan manusia. Lewat mitos ini manusia dapat turut serta mengambil bagian dalam kejadian-kejadian sekitarnya dan dapat menanggapi daya-daya kekuatan alam.Dengan kata lain sebagaimana dikatakan Purwadi, bahwa mitos berfungsi menyadarkan manusia akan adanya kekuatan-kekuatan ajaib, memberikan jaminan bagi manusia masa kini dan sebagai pengantar antara manusia dengan daya-daya kekuatan alam. .(Purwadi, 2005: 202).

Hampir seluruh aktifitas masyarakat jawa, dipenuhi dengan tradisi-tradisi simbolik yang sarat dengan makna kearifan lokal (local wisdom). Dari awal kehidupan seorang manusia sampai akhir kehidupannya ada tradisi, ritual tertentu yang harus dilakukannya agar "sempurna" menjadi orang jawa. Terlepas dengan adanya pergeseran makna dari tradisi tersebut, tapi seseorang (jawa) merasa tidak nyaman jika tidak melakukan tradisi tersebut. Sebut saja beberapa acara sinoman dalam masyarakat jawa seperti ngerjake sawah (mengerjakan sawah), nduwe gawe (hajatan), kesripahan (kematian), dan ngedekke omah (mendirikan rumah)

Dalam hal mendirikan rumah ada tradisi munggah molo adalah selamatan yang mengiringi dinaikkannya atap tertinggi dari rumah yang sedang dibangun. Biasanya diawali pada Rabu malam dengan pembacaan doa, dengan mengundang para tonggo teparo (tetangga sekitar rumah), termasuk para tukang, serta mengundang seorang ustadz atau Kiai yang terkadang disertai dengan wejangan. Menu makanan pun disajikan, untuk dinikmati bersama bagi yang ingin langsung menikmatinya atau kalau mau dibawa pulang juga mudah karena sudah disediakan plastik atau kotak kardus. Selanjutnya setelah selesai ada acara yang informal yaitu lek-lekan (begadang).

Pada esok harinya, tepatnya hari Kamis sekitar jam 12 siang atau usai dhuhur, diadakan selamatan lagi sebelum menaikkan molo. Kali ini hanya melibatkan para tukang (memang untuk merekalah sebenarnya acara ini diselenggarakan) dan mengundang beberapa tetangga dekat saja. Juga dengan mengundang Pak Ustadz yang tadi malam untuk menyampaikan sedikit wejangan dan memimpin doa.

Sebelum doa, para tukang memasang bendera merah-putih yang sudah dibuat semacam kantong. Lalu masih ada setundun pisang, seonggok padi yang sudah menguning, buah kelapa dan seikat tebu, yang kesemuanya juga diikat dan digantungkan pada blandar. Tidak ketinggalan beberapa keping uang receh dan paku emas yang dimasukkan ke dalam 
kantong bendera mereh puth yang lalu juga digantungkan di blandar. Lalu ada stagen (bengking) yang dipasang di blandar menjulur ke bawah dengan diberi ember berisi air di ujung bawah stagen.

Selanjutnya, para tukang lalu kumpul melingkari nasi tumpeng yang dilengkapi gudangan (urap), tempe, ayam goreng, telur, lalapan plus sambalnya, dan lain sebagainya.. Masih ada lagi, jajan pasar komplit (jadah pasar), buah-buahan komplit., sewadah bunga dan banyak lagi ubo rampe yang lainnya. Setelah itu doa dibacakan oleh seorang tokoh masyarakat (kiai), calon pemilik rumah memotong tumpeng yang kemudian diberikan kepada salah satu anggota keluarganya.

Masyarakat Kabupaten Pekalongan sebagai bagian dari kebudayaan jawa yang terletak di wilayah pesisir pantai utara jawa juga melakukan tradisi munggah molo sejak dulu dan masih dilakukan sampai sekarang. Bagi masyarakat pekalongan yang mayoritas beragama Islam. Pada ritual yang sudah mentradisi ini (munggah molo) tidak dipungkiri memang penuh dengan nuansa mistis yang terkadang sukar dicerna oleh logika, atau terkadang "bersinggungan" dengan syariat Islam. Meskipun demikian, faktanya Berbagai macam tradisi yang kaya akan keindahan itu masih hidup dan diyakini pemahamannya oleh sebagian besar masyarakat di Pekalongan dari berbagai kalangan dan etnis.

Dalam tradisi munggah molo, banyak hal-hal yang harus diungkap dan dipahami oleh banyak masyarakat, sehingga masyarakat dapat menempatkan serta memahami mana tradisi dan mana kepercayaan. Demikian juga bentuk-bentuk kebahasaan yang terdapat dalam tradisi ini sangat unik baik itu bentuk-bentuk simbolik maupun penamaan. Seperti halnya kenapa harus "bendera merah putih", "seikat padi", setundun "pisang", "pohon tebu", "4 buah kelapa, "kepingan-kepingan "uang receh" yang digunakan? Kenapa tidak yang lainnya?. Demikian juga dalam penamaan, kenapa dinamai "molo", "blandar", dan lain sebagainya. Demikian juga, dalam praktiknya kenapa "molo" harus dinaikan hari kamis setelah dluhur? Juga kenapa juga harus “lek-lek an"?, dan lainnya

Melihat uniknya tradisi munggah molo yang terdapat di Pekalongan (karena berbeda dengan daerah lain di jawa) serta saratnya makna dan nilai-nilai yang terkandung di dalamnya tersebut. Peneliti ingin mengetahui bentuk-bentuk kebahasaan (bahasa verbal atau simbol) yang terdapat dalam tradisi tersebut. Demikian juga pengetahuan tentang makna serta keterkaitan fungsi tradisi ini terhadap kehidupan sosial mengingat tradisi ini juga dilakukan oleh sebagaian warga pekalongan dari etnis tionghoa dan arab.

\section{Kondisi sosial Masyarakat Pekalongan}




\subsection{Sejarah Pekalongan}

Pekalongan adalah sebuah nama untuk kabupaten dan kota yang terletak di wilayah pesisir pantai utara jawa pada $109^{\circ}-109^{\circ} 78^{\prime}$ bujur timur dan antara $6^{\circ}-7^{\circ} 23^{\prime}$ Lintang Selatan. Kabupaten Pekalongan yang beribukota Kajen dan memiliki motto SANTRI (Sehat, Aman, Nyaman, Tertib, Rapi, Indah) ini memiliki luas wilayah $836.13 \mathrm{~km} 2$ dan memiliki 19 kecamatan ini sebelah selatan berbatasan dengan kabuapaten Banjarnegara, sebelah barat dengan kabupaten Pemalang, sebelah timur dengan kabupaten Batang dan sebelah utara berbatasan dengan kota Pekalongan dan pantai utara Jawa.(Tim Litbang Kompas, 2003: 177). Sedangkan Kota Pekalongan yang bersemboyan kota BATIK (Bersih, Aman, Tertib, Indah, Komunikatif) yang terletak mempunyai luas wilayah $45.25 \mathrm{~km} 2$ dengan 4 wilayah kecamatan. Wilayah selatan berbatasan dengan Kabupaten Pekalongan dan Batang, utara berbatasan dengan laut jawa dan sebelah barat juga berbatasan dengan kabupaten pekalongan. .(Tim Litbang Kompas, 2003: 222).

Pekalongan, baik kabupaten maupun kota memiliki akar sejarah yang sama. Nama Pekalongan sendiri dalam sejarahnya ada beberapa versi, salah satunya adalah legenda tentang Raden Bahurekso yang waktu itu akan membuka hutan gambaran atau gambiran disebut pula muara gambaran- yang lebat lagi angker dan banyak dihuni makhluk halus yang jahat juga binatang-binatang buas. Agar misinya berhasil untuk mengalahkan itu semua, Raden Bahurekso melakukan semedi tapa ngalong yaitu menggantungkan diri terbalik di pohon seperti hewan kalong. Setelah tujuannya berhasil dan sukses, kota itupun dinamakan dengan Pekalongan.

Hari Jadi Kabupaten Pekalongan telah ditetapkan pada Hari Kamis Legi Tanggal 25 Agustus 1622 atau pada 12 Robiu'l Awal $1042 \mathrm{H}$ pada masa pemerintahan Kyai Mandoeraredja, beliau merupakan Bupati/Adipati yang ditunjuk dan diangkat oleh Sultan Agung Hanyokrokusumo / Raja Mataram Islam dan sekaligus sebagai Bupati Pekalongan I, sedangkan penentuan hari dan tanggalnya diambil dari sebagaimana tradisi pengangkatan Bupati dan para pejabat baru di Mataram.

Pembangunan Kabupaten Pekalongan sudah dilakukan sejak zaman Pemerintahan Adipati Notodirdjo (1879 -1920 M) di komplek Alun-alun utara no 1 Kota Pekalongan, bangunan tersebut merupakan rumah bagi para Bupati Pekalongan sekaligus sebagai tempat aktivitas perangkat pemerintahan dengan berbagai elemen masyarakat untuk bersilaturakhmi, bermusyawarah dan mencurahkan pemikiran atau unek-unek berbagai kehendak di hadapan bupati.

Proses pemindahan Ibukota Kabupaten Pekalongan diawali dengan peresmian 
sekaligus penggunaan Gedung Sekretariat Daerah Kabupaten Pekalongan di Kajen oleh Bupati Drs. H Amat Antono pada tanggal 25 Agustus 2001, kepindahan itu merupakan salah satu tonggak sejarah sebagai momen diawalinya kota kecamatan Kajen sebagai Ibukota Kabupaten Pekalongan.

Secara bertahap pembangunan untuk melengkapi prasarana menjadi simpul-simpul penggerakan dan pengembangan sebagai sebuah ibukota kabupaten juga telah dibangun rumah dinas Bupati dan Pendopo yang selesai bertepatan dengan hari Jum'at Pon 19 Dzulhijjah $1423 \mathrm{H}$ atau tanggal 21 Pebruari 2003 yang diresmikan secara langsung oleh Menteri Dalam Negeri Bapak Hari Sabarno atas nama Presiden Republik Indonesia Ibu Hj. Megawati Soekarnoputri pada tanggal 5 April 2003. Untuk peringatan hari jadi Kabupaten Pekalongan pada tahun 2015 ini adalah merupakan peringatan hari jadi yang ke 392 tahun.(www.pekalongankab.go.id).

\subsection{Potret Sosial Budaya Pekalongan}

Kota kota dan daerah di pesisir pulau jawa, khususnya pekalongan. Masyarakatnya sedang mengalami transisi dalam kehidupan sosialnya, ini akibat dampak adanya industrialisasi yang mulai meninggalkan pertanian (agraris). Perubahan tersebut dapat dilihat di antaranya dengan menurunnya hasil di bidang pertanian. Hal ini dipengaruhi oleh beberapa faktor antara lain: semakin menyempitnya lahan pertanian yang disebabkan oleh adanya pengalihan pemberdayaan lahan pada bidang non pertanian yaitu pembangunan gedunggedung bertingkat maupun untuk usaha lain seperti industri, baik industri berskala kecil sampai industri dengan skala besar. Pengaruh yang lain seperti berkurangnya minat para pemuda khususnya sebagai generasi penerus di bidang pertanian. Pada umumnya golongan muda di pedesaan sudah tidak begitu tertarik untuk bekerja di sektor pertanian. Para pemuda di pedesaan umumnya mempunyai berbagai alasan tersendiri seperti: bidang pekerjaannya relatif berat, efektifitas kerja tergantung musim, penghasilan tidak menentu, pendapatan relatif rendah dan kurang pasti. (Fatimah, 2005: 2).

Dari aspek budaya, sebagai sebuah wilayah di pesisir utara pulau jawa Pekalongan telah memiliki sejarah panjang, dari zaman pra sejarah sampai zaman kemerdekaan dan sekarang ini. Dalam rentang sepanjang itu Pekalongan tidak pernah lepas dari pengaruh peradaban, kebudayaan dari pemerintah atau kerajaan yang menguasai jawa seperti Demak dan Mataram Islam yang sangat kental dengan tradisi jawa.Karena memang pekalongan pernah berada dalam kekuasaan dua kerajaan besar tersebut. Karena itu mempelajari budaya pekalongan tak bisa dilepaskan dari memahami budaya jawa secara umum. 
Kebudayaan jawa menurut Purbatjaraka bersal dari kitab-kitab atau dongeng berbahasa jawa (Purbatjaraka, 1952: VII-IX). Adapun bahasa jawa adalah bahasa dari rumpun Austronesia, yaitu bahasa asli yang dipergunakan oleh bangsa-bangsa asli yang menempati kepulauan di sebelah tenggara benua Asia. Pada perkembangannya kebudayaan jawa adalah akulturasi dari berbagai unsur asing seperti agama Hindu, Budha, dan Islam (Purwadi, 2005: 9-13).

Masyarakat pekalongan -sebagaimana orang jawa- cenderung memiliki sikap nrimo (menerima) dan pasrah terhadap kehidupan yang sedang berjalan karena itu merupakan takdir yang telah ditentukan oleh Tuhan. Ini bisa karena keyakinan teologis atau karena pengaruh sosial budaya. Seperti yang dikemukakan oleh Mulder, (Dany Setyaningsih, 2006: 22-23) bahwa nrimo berarti tahu tempatnya sendiri, berarti percaya pada nasib sendiri dan berterima kasih pada Tuhan karena ada kepuasan dalam memenuhi apa yang menjadi bagiannya dengan kesadaran bahwa semuanya telah ditetapkan. Hal ini berarti orang Jawa mempunyai kewajiban moral untuk menghormati tata kehidupan yang ada di dunia ini. Mereka harus menerima kehidupan sebagaimana adanya sambil berusaha sebaik-baiknya dan menumbuhkan kedamaian jiwa serta ketenangan emosi.

Masyarakat Pekalongan mempunyai beberapa ritual untuk mempertahankan, melanjutkan atau memperbaiki tatanan kehidupan yaitu dengan mengadakan slametan yang terkadang merupakan akulturasi dari budaya jawa asli (hindu) dengan Islam. Hal ini bisa dilihat dari beberapa tradisi yang sudah jamak dilakukan masyarakat seperti slametan kehamilan (mitoni), kelahiran (bancakan cukur bayi), slametan kematian (nelong dino, mitong dino, matang puluh dino dan lainnya), mendirikan rumah (sambatan, munggah molo) dan sebagainya. Tujuan slametan menurut Koentjaraningrat (Koentjaraningrat, 1986) adalah untuk mencapai keadaan slamet, yaitu suatu keadaan di mana peristiwa-peristiwa akan bergerak mengikuti jalan yang telah ditetapkan dengan lancar dan tidak akan terjadi kemalangan kemalangan kepada sembarang orang. Jadi maksud diadakannya slametan oleh orang Jawa adalah agar terlindungi dari segala bahaya dalam kehidupan di dunia ini, sehingga dapat melaksanakan kehidupan yang diinginkannya dengan lebih baik.

Secara umum budaya masyarakat pekalongan adalah budaya yang merupakan perpaduan dari tradisi jawa dan ajaran-ajaran keagamaan (Islam). Tradisi jawa adalah tradis yang berlandaskan pada pandangan hidup jawa atau filsafat jawa yang terbentuk dari gabungan pola pikir jawa tradisional, kepercayaan hindu atau filsafat india dan ajaran tasawuf atau mistik Islam. Sebagai pandangan hidup itu banyak tertuang dalam karya sastra puisi dan prosa. .(Purwadi, 2005: 3). Meskipun pengaruh tradisi jawa di Pekalongan tidak begitu kuat 
dibandingkan daerah-daerah jawa lainnya di "pedalaman" seperti Yogyakarta, Solo, Magelang dan lainnnya yang cenderung lebih kuat pengaruh jawanya karena memang kotakota tersebut merupakan pusat-pusat kebudayaan jawa. Juga, Pekalongan sebagaimana kota kota di pesisir laut jawa yang masyarakatnya diidentikkan dengan masyarakat jawa yang santri sebagaimana pemilahan Geertz tentang santri, priyayi dan abangan.

Kabupaten Pekalongan kaya akan budaya tradisional. Berbagai macam kesenian tradisional banyak dimiliki beberapa desa dan kecamatan di wilayah Kabupaten Pekalongan yang tentu saja dengan ciri khas masing - masing. Keanekaragaman itu tidak memecah belah masyarakat tapi justru semakin memperkaya khasanah budaya di daerah Kabupaten Pekalongan. Di antaranya adalah: Upacara Tradisi Syawalan adalah agenda tahunan yang diselenggarakan oleh Kantor Pariwisata dan Kebudayaan Kabupaten Pekalongan seminggu setelah Hari Raya Idul Fitri, Kesenian Kuntulan/Sirkus "Gralis Budaya"Sabarwangi Kajen,

Kesenian Kuda Kepang dari Desa Wonorejo, Kecamatan Wonopringgo, Kabupaten Pekalongan, Kesenian Jaran Ilir Kecamatan Sragi dan sebaaginya. (www.pekalongankab.go.id).

\section{Munggah Molo di Pekalongan}

\subsection{Sejarah Munggah molo di Pekalongan}

Tradisi munggah molo adalah tradisi jawa yang dilakukan oleh hampir di semua masyarakat jawa di berbagai wilayah, termasuk di pekalongan. Karena itu menelusuri sejarah awasal muasal munggah molo bukanlah pekerjaan mudah. Karena itu berkaitan dengan peradaban jawa kuno yang memang sukar untuk dipahami secara konkrit

Paling tidak untuk bisa mengetahui sejarah munggah molo, maka seseorang harus memahami arah pemikiran filsafat jawa. Ciri pandangan hidup orang Jawa adalah realitas yang mengarah kepada pembentukan kesatuan numinus antara alam nyata, masyarakat dan alam adikodrati yang dianggap keramat. Alam adalah ungkapan kekuasaan yang menentukan kehidupan. Orang Jawa percaya bahwa kehidupan mereka telah ada garisnya, mereka hanya menjalankan saja.

Secara kosmologi, kehidupan di dunia merupakan bagian dari kesatuan eksistensi yang meliputi segalanya (Neils Mulder, 1996: 19). Dalam kesatuan itu, semua gejala mempunyai tempat dan berada dalam hubungan-hubungan yang saling melengkapi dan terkoordinasi satu sama lain. Gejala-gejala ini merupakan bagian dari satu perencanaan besar. Perencanaan itu digambarkan sebagai suatu susunan yang teratur dimana peristiwa-peritiwa tidak terjadi karena suatu kebetulan melainkan suatu keharusan. Karena seluruh jagat ini satu 
sama lain saling berhubungan. Kesemuanya itu menurut orang jawa harus bisa hidup damai, selaras, serasi, dan seimbang sehingga dalam laku kehidupan, orang jawa cenderung tidak mau diganggu dan mengganggu. Karena itu, meski orang jawa sepenuhnya percaya kepada yang Maha Esa, tetapi mereka juga masih melakukan "tegur sapa" kepada hal-hal gaib dalam setiap aspek kehidupan mereka. Ini mereka lakukan demi keselarasan kosmos tadi,(Giri MC, 2010: 17) termasuk dalam tradisi munggah molo.

Bagi masyarakat pekalongan, mereka sudah lama melaksanakan tradisi munggah molo. Mereka tidak pernah menyadari sejak kapan sebenarnya tradisi itu muncul. Sebagaimana diungkapkan oleh tokoh masyarakat yang sekaligus pelaku munggah molo, Wahmudi (60 tahun) :

Yo, asale munggah molo kui warisane nenek moyange mbah mbah sesepuh mbiyek.mboh kui budho opo islam, sing jelas nenek moyang.

(Ya, asal muasal munggah molo itu tak jelas, pokoknya itu warisan dari nenek moyang dan para sesepuh dahulu. Baik Budha maupun Islam, yang jelas nenek moyang)

Apa yang disampaikan oleh Wahmudi senada dengan apa yang diungkapkan oleh Kiptiyah (58 tahun) yang juga menyatakan bahwa tradisi munggah molo memang sudah dilakukan sejak lama, pokoknya awit aku melek wis ono.

Tradisi munggah molo memang sudah ada sejak lama di Pekalongan, bahkan tradisi ini juga dilakukan oleh kalangan Tionghoa dan Arab. Menurut Kiptiyah, bahwa dahulu di desanya ada seoarang kyai yang berpengaruh yang bernama KH. Ahmad, kyai ini terkenal dalam bidang pengobatan dan konsultasi sosial (tabib). Banyak di antara tamunya yang berkunjung selainorang jawa adalah warga Tionghoa dan Arab yang terkadang minta do'a ketika akan melakukan tradisi munggah molo saat mendirikan rumah.

Menurut Kholid (60 th), seorang warga keturunan Arab di daerah Klego, bahwa tradisi munggah molo pada masyarakat keturunan Arab, terkadang dilakukan, tetapi itupun biasanya yang mempunyai inisiatif adalah tukang atau pekerja yang membangun rumah. Artinya kalaupun dilaksanakan itu sepertinya hanya untuk menuruti para pekerja saja. Sementara menurut yang lainnya, Muhsin (25 th) yang bertempat di daerah Krapyak misalnya menyatakan kalau selamatan munggah molo sih ada, tapi ubo rampe yang seperti orang jawa itu jarang dilakukan.

Sementara pada masyarakat keturunan Tionghoa, bahwa tradisi munggah molo sebenarnya juga ada, tapi bentuknya tidak seperti yang dilakukan oleh orang-orang jawa. Sebagaimana yang dikatakan Wahidin (40 th), seorang pekerja di keluarga keturunan Tionghoa : 
Yo, sak retiku ono sih, tapi yo sekedar selametan. Ora koyo wong jowo sing macemmacem anggo ubo rampene.

(Ya, setahu saya sih ada upaca seperti itu, tapi ya sekedar selamatan. Tidak sepeerti orang jawa yang bermacam-macam ubo rampe)

Perlu atau tidaknya seseorang melakukan ritual munggah molo bagi masyarakat pekalongan mendapatkan jawaban yang berbeda-beda. Tetapi intinya mereka tetap melakukan tradisi munggah molo. Jadi ada masyarakat yang melaksanakan tradisi ini memang karena mengerti makna dan fungsinya, tapi ada juga yang melakukan karena mengikuti tradisi saja tanpa tahu maknanya secara pasti.

Oleh karena itu dalam hal perlu atau tidaknya melaksanakan munggah molo, ada yang berpendapat memang perlu dilkasanakan karena kalau tidak akan menyebabkan terjadinya hal-hal yang tidak diinginkan, sebagaimana jawaban dari Wahmudi berikut ini :

Omah sing ora dilakoni munggah molo ngko biasane omahe cepet rusak, wong sing nunggoni omah lan bocah-bocahe do meler karo mriyangan.

(Rumah yang tidak dilaksanakan tradisi munggah molo, biasanya cepat rusak, para penghuni dan anak-anaknya sering sakit-sakitan).

Sementara itu menurut Kiptiyah, persoalan mau melaksanakan atau tidak melaksanakan tradisi munggah molo itu adalah soal keyakinan. Artinya kalau hatinya yakin tidak apa-apa jika tidak melakukan, insya Allah tidak apa-apa. Tapi kalau ragu-ragu, takut terjadi apa-apa jika tidak melakukan. Bisa saja memang nantinya terjadi sesuatu.

Masih menurut Kiptiyah, bahwa konon ada orang yang membuat rumah tanpa melaksanakan tradisi munggah molo. Entah kebetulan atau tidak, isteri dari pemilik rumah ini mengalami gangguan jiwa. Cerita ini memang ada turun temurun. Bahkan menurut Mustafa, di tetangga desa katanya ada rumah yang roboh karena tidak melaksanakan munggah molo.

\subsection{Prosesi Munggah molo di Pekalongan}

Pada saat mendirikan rumah, biasanya setelah tembok sisi kanan kiri sudah terpasang, kalau jaman dahulu adalah kayu-kayu penyangga "pager" (bambu yang dianyam) sudah terpasang, maka saatnya melakukan tradisi munggah molo, yaitu selamatan yang mengiringi dinaikkannya atap tertinggi dari rumah yang sedang dibangun.

Biasanya prosesi diawali sejak hari rabu malam yaitu do'a bersama dengan para tetangga, tokoh masyarakat, kiyai atau ustad serta juga beberapa orang dari tukang. Menurut orang jawa termasuk masyarakat pekalongan, hari rabu dipandang sebagai hari yang baik untuk mengawali melakukan sesuatu. Menurut mereka hari rabu memberikan rasa tentram 
dan "ngademi", di samping hari, waktu juga dicari yang baik, menurut perhitungan mereka, waktu yang baik untuk menaikkan molo adalah sekitar jam 11 siang (hampir dzuhur) hari kamis.Demikian dikatakan oleh Wahmudi. Akan tetapi pada masa sekarang, biasanya justeru dilakukan pada malam hari yaitu malam kamis atau malam jumat, karena untuk mengundang orang atau tetangga pada siang hari sudah sulit dikarenakan ada kesibukan baik bekerja atau keperluan lain.

Selanjutnya tuan rumah mengundang para tetangga sekitar rumah, termasuk para tukang yang mengerjakan membuat rumah, serta mengundang seorang sesepuh, ustadz atau Kiai yang nanti akan berdoa, inilah yang dahulu dinamakan dengan "kidung" yang berarti "kiai ndunga" atau kiai berdoa. Kalau jaman dahulu kidung diisi dengan kidung (lagu) dan puji-pujian, sekarang biasanya diisi dengan tahlilan, solawatan, atau manakiban. Manakiban yang biasa dibaca adalah manakiban Syekh Abdul Qodir Jailani.(wawancara dengan Wahmudi).

Kadang-kadang setelah itu disertai dengan mauidhah hasanah sekedarnya. Menu makanan pun disajikan (biasanya berupa sego golong dengan lauk panggang ayam), ayam biasanya dimasak utuh atau sakgluntung, setelah doa selesai salah seorang memotongmotong ayam yang kemudian dimasukan ke dalam sego golong yang dibungkus dengan daun pisang yang sudah disediakan. Sajian sego golong dan lauknya ini bisa dinikmati bersama bagi yang ingin langsung menikmatinya atau kalau mau dibawa pulang juga boleh. Tuan rumah sudah menyediakan plastik atau kotak kardus. Setelah ini prosesi awal selesai, malam harinya (malam kamis) beberapa orang tetangga datang ke tempat upacara tadi siang untuk sekedar lek-lekan (begadang) dengan pemilik rumah. Hal inilah yang kemudian mengubah waktu selamatan yang seharusnya siang beralih pada malam hari, agar tamu tidak bolakbalik, tapi selesai selamatan bisa langsung lek-lekan.

Pada esok harinya, tepatnya hari Kamis sekitar jam 12 siang atau usai dhuhur, diadakan selamatan lagi sebelum menaikkan molo. Kali ini hanya melibatkan para tukang (memang untuk merekalah sebenarnya acara ini diselenggarakan) dan mengundang beberapa tetangga dekat saja. Juga dengan mengundang sesepuh atau kyai yang tadi malam untuk menyampaikan sedikit wejangan dan memimpin doa.(wawancara dengan Mustafa).

Sebelum doa, para tukang memasang bendera merah-putih yang sudah dibuat semacam kantong dan ini namanya molo. Molo dipasang di tengah kayu salam yang memanjang Lalu masih ada setundun pisang sepet, seonggok padi yang sudah menguning, 4 buah kelapa dan seikat tebu, yang kesemuanya juga diikat dan digantungkan pada blandar. Tidak ketinggalan beberapa keping uang receh dan uwat-uwat dimasukkan ke molo. Juga ada 
paku emas ${ }^{1}$ yang dimasukkan ke dalam atau dipakukan ke kantong bendera mereh putih yang lalu juga digantungkan di blandar. Di samping itu ada juga sarung atau baju yang ikut dipasang di atas yang bermakna agar mendapat keberkahan sandang, Lalu ada stagen (bengking) yang dipasang di blandar menjulur ke bawah dengan diberi ember berisi air di ujung bawah stagen.(wawancara dengan Wahmudi).

Semua ubo rampe tadi dinaikkan bersama molo oleh para tukang yang membangun rumah, setelah dinaikkan, sesepuh atau kyai berdoa. Selanjutnya, para tukang lalu kumpul melingkari nasi tumpeng atau golong yang dilengkapi gudangan (urap), tempe, ayam goreng, telur, lalapan plus sambalnya, dan lain sebagainya.. Masih ada lagi, jajan pasar komplit (jadah pasar), buah-buahan komplit. Yang jelas, kalau jaman dahulu, ubo rampe yang ada itu berfungsi sebagai sesaji. Sekarang semua yang dipasang itu diperuntukkan bagi manusia, biasanya diambil atau diserahkan kepada para tukang. Adapun yang tetap ditinggal adalah molo yang digantung atau dipaku tersebut.(wawancara dengan Wandi)

Wandi menuturkan, bahwa setelah prosesi munggah molo dilaksanakan, maka para tukang sudah mulai "berani" memasang genteng sebagai atap. Karena itu biasanya yang mengusulkan atau yang tahu persis kapan munggah molo dilaksanakan adalah para tukang, yang terkadang merasa ikut berkepentingan dengan "keselamatan" diri mereka, di samping juga ada kepentingan lainnya seperti mendapat manfaat materi dari adanya tradisi ini. Karena kalau tidak dilaksanakan dikhawatirkan proses pembuatan rumah selanjutnya akan ada rintangan atau halangan baik dari aspek para tukangnya maupun dari tuan rumah dan keluarganya atau justru dari bangunan rumah itu sendiri.

Jadi, terlepas dari motif yang mendorong dilaksanakannya munggah molo dari para tukang atau calon pemilik rumah. Yang jelas, tradisi ini tetap dilaksanakan. Meskipun pada masa sekarang, terkadang ubo rampe yang disajikan tidak mesti lengkap atau ada perubahan sesaji. Misalnya nasi golong terkadang untuk masa sekarang sudah digantikan dengan satu kotak kardus roti, karena dianggap lebih efisien.

Hal ini adalah sesuatu yang wajar terjadi pada tradisi di manapun, terutama adalah daerah-daerah yang mengalami masa transisi, termasuk masyarakat jawa yang dikategorikan sebagai masyarakat yang sedang berada dalam keadaan transisional. Masyarakat bergerak dari masyarakat agraris tradisional yang penuh dengan nuansa spiritualistik menuju masyarakat industrial modern yang materealistik. Menurut Durkheim, keadaan tersebut

\footnotetext{
${ }^{1}$ Paku emas ini, bentuknya kecil sekali. Biasanya hampir mirip dengan jarum, tetapi lebih besar sedikit. Untuk mendapatkannya biasanya bisa dibeli pada tukang patri mas yang memang sudah biasa menerima pesanan. Kiptiyah, warga Pekalongan, wawancara pribadi, 10 Februari 2015.
} 
dikategorikan sebagai masyarakat yang penuh solidaritas organik. Dalam masyarakat seperti itu kemungkinan akan muncul fenomena kegalauan budaya (pada tingkat individu) yang disebut oleh Durkheim dengan istilah Anomie.(Safri Sairin, 2002: 13).

\section{Makna Leksikon dan Simbol dalam Tradisi Munggah Molo}

Di dalam tradisi Munggah Molo ditemukan beberapa leksikon bahasa dan simbol yang terkait di dalamnya. Adapun kumpulan leksikon serta simbol yang biasa digunakan dalam Munggah Molo adalah:

1. Munggah

Secara leksikal kata "munggah" berasal dari bahasa Jawa yang berarti "naik". Dalam tradisi Munggah Molo, naik disini dalam hal menaikan tiang tertinggi untuk atap rumah yang sering disebut sebagai "blandar". Simbol dari kata "munggah" dalam upacara Munggah Molo adalah peningkatan kualitas makna hidup seseorang (calon pemilik rumah).

2. Molo

Kata "Molo" juga berasal dari bahasa Jawa. Molo merupakan derivat dari kata "polo" yang berarti "kepala"(wawancara dengan Wahmudi). Ada juga yang mengartikannya sebagai "otak". Sementara "Molo" sendiri diartikan sebagai bagian tertinggi dari sebuah rumah. Karena kata "Molo" berasal dari kata "polo" yang berarti "otak" atau bagian anatomi tubuh yang paling atas, maka maksud simbolik dari "Molo" adalah sesuatu yang menjadi tujuan inti atau pusat dari sebuah rumah. Konsekwensinya, sebuah rumah dapat ditempati setelah "Molo" rumah tersebut dinaikan dan diadakan upacara Munggah Molo.

3. Blandar

Kata "Blandar" juga diambil dari bahasa jawa yang berarti "bos", atau yang menguasai, seperti contoh "blandar dom" (bos judi)". Tetapi seiringan perubahan semantis "blandar" dapat diartikan sebagai kayu penyangga atap"(Suwito, 2007: 27), biasanya kayu ini lebih besar dari kayu yang lainnya, karena menjadi tumpuan dari kayu-kayu yang lainnya. Makna simbolik dari keberadaan blandar dalam sebuah bangunan rumah adalah dalam kehidupan semestinya mempunyai pegangan yang kokoh, sebagai "way of life".

4. Kayu salam

Kayu salam adalah sejenis kayu yang diambil dari pohon salam. Awalnya kayu salam ini digunakan untuk "blandar". Makna simbolik awal dari pemakaian kayu salam 
adalah agar rumah selalu dinaungi keselamatan.(wawancara dengan Wahmudi). Akan tetapi, penggunaan kayu salam sebagai blandar saat ini sudah digantikan dengan kayu Glugu atau pohon kelapa.

5. Pari

Pari atau pantun berarti padi. Dalam prosesi Munggah Molo, benda mempuanyai makna simbolik yang sangat dalam yaitu diantaranya; rumah harus sejahtera, terpenuhi kebutuhan pangannya, status sosial.

6. Tebu

Tebu berasal dari bahasa Indonesia yang berarti tebu, sebuah pohon yang biasa digunakan bahan dasar dalam membuat gula. Keberadaan tebu dalam tradisi Munggah Molo di Pekalongan mempunyai makna simbolik yaitu kehidupan seseorang harus banyak menanam kebaikan.

7. Bengking

Kata "bengking" berasal dari bahasa Jawa yang berarti stagen, sejenis kain panjang yang dipakai untuk melangsikan perut perempuan. Dalam tradisi Munggah Molo, biasanya bengikng dipasang di bawah Molo menjulur sampai ke lantai yang sudah disiapkan baskom berisi air. Makna simbolikny adalah agar para penghuni rumah nantinya berumur panjang sebagaimana bengking dan memiliki sifat kesabaran. Makna kesebaran disini diambil dari simbol air yang berada di dalam baskom, dan sifat air adalah mendinginkan.(wawancara dengan Wandi)

8. $\quad$ Sego Golong

Sego berarti "nasi", golong berarti" bulatan". Jadi sego golong adalah nasi yang dalam bentuk bulatan. Simbol nasi disini dimasudkan agar orang yang membuat selamatan dalam menapaki setiap perjalanan waktu untuk mengarungi kehidupan selalu diberi keselamatan dan berhasil meraih apaya yang dicita-citakannya, Karena sego golong melambangkan kebulatan tekad yang manunggal.(Giri MC, 2010: 23)

9. Duit recehan

Duit berarti uang, recehan berarti kecil. Duit recehan berarti uang kecil. Dalam prosesi Munggah Molo uang-uang recehan ini disimpan di dalam kantong dan digantung dalam Molo bersama uwat-uwat. Makna simbolik dari uang receh adalah modal atau bantuan dari para tetangga.Karena memang uang ini didapat dari para tetangga secara sukarela.(wawancara dengan Wahmudi) Maknanya adalah bahwa setiap orang memerlukan bantuan orang lain.

10. Paku mas 
Paku mas berarti paku kecil yang terbuat dari emas murni. Dalam Munggah Molo, paku emas biasanya digunakan untuk memaku Molo di kayu blandar. Paku mas dipercaya mampu memberikan kekuatan pada rumah disamping juga memberikan umur panjang.

11. Gedang Sepet

Gedang berarti pisang, sepet artinya asam. Gedang sepet adalah pisang asam. Gedang sepet bukan berarti rasa pisang ini asam akan tetapi itu hanya nama pisang, adapun rasanya tetap manis. Gedang sepet juga sama seperti ubu rampe yang lainnya yang dipasang di atas Molo. Makna simbolik dari gedang sepet adalah seseorang dalam menjalani hidup harus berani sepet atau prihatin, karena itu semuanya sebenarnya adalah manis.

12. Juadah pasar

Juadah pasar adalah nama makanan yang terbuat dari beras ketan yang dikukus kemudian ditumbuk. Pada perkembangannya juadah pasar tidak hanya makanan dari ketan saja, tapi adalah jajanan komplit dari pasar. Dalam proses Munggah Molo, barang ini digunakan untuk dijadikan sajen para sanak saudara dan tetangga. Makna simbol dari makanan ini adalah sebagai penghormatan penguasa lautan, biasanya kepercayaan ini dilakukan oleh masyarakat pesisir.(Giri MC, 2010: 34)

13. Gendero Abang Putih

Gendero Abang Putih berarti bendera merah putih. Kain merah putih ini kemudian dijahit menjadi kantung Molo, yang digunakan untuk menyimpan uwat-ueat, uang receh, dan ubu rampe lainnya. Bendera merah putih ini mempunyai makna simbolik yaitu menunjukan rasa kecintaan tanah air, terutam apada masa-masa penjajahan.

14. Baskom

Baskom adalah semacam wadah yang terbuat dari bahan kaleng atau kuningan. Fungsinya digunakan untuk mewadahi air sebagai perendam ujung benging yang diikatkan di atas Molo. Simbol dari baskom ini adalah sebagai hati yang senantiasa dingin dan sabar dalam menjalani kehidupan.

15. Payung

Payung adalah, sebuah benda yang digunakan untuk berlindung ketika hujan atau panas. Payung ini dipasang di atas bersama Molo. Makna simbol dari payung adalah bahwa rumah adalah sebuah tempat yang bisa menaungi penghuninya dari segala halhal yang membahayakan. Oleh karena itu, ketika rumah sudah jadi orang Jawa dianggap tidak sopan jika memakai payung di dalam rumah.(Purwadi, 2005: 227) 
16. Kelopo

Kelopo artinya kelapa. Biasanya dipasang di atas bersama Molo. Benda ini memiliki makna simbol bahwa manusia harus memiliki manfaat dalam kondisi apapun.

17. Kidung

Kata kidung berasal dari bahasa jawa yang berarti nyanyian. Nyanyian ini biasanya berisi puji-pujian kepada yang Maha Kuasa. Pada perkembangan selanjutnya, kidung ini diartikan sebagai "Kiai ndungo", yaitu kiai berdo'a.(wawancara dengan Wamudi). Karena itu pada acara Munggah Molo biasanya istilah kidung sudah tidak dipakai lagi dan sekarang digantikan bacaan al-Qur'an, sholawatan, dan manakiban.

18. Uwat-uwat

Uwat berasal dari bahasa Jawa yang berarti obat. Uwat-uwat juga diletakan di atas dimasukan ke dalam Molo. Makna simbolik dari uwat-uwat adalah memberikan kekuatan kepada rumah dan memeberikan umur panjang.

19. Kembang Setaman

Kembang berarti bunga, setaman berarti sekebun. Kembang setaman di sini dimaksudkan bunga-bunga yang bermacam-macam (lengkap). Makna simbolik dari Kembang setaman adalah memancarkan keharuman. Sehingga menarik orang atau tamu dan penghuninya merasa betah di rumah.

20. Ayam panggang

Ayam panggang atau ayam pecel adalah ayam yang dimasak secara utuh yang kemudian disiram dengan bumbu berupa santan. Ayam ini dimaksudkan sebagai simbol mensucikan orang yang punya hajat.(Giri MC, 2010: 26)

21. Boreh

Boreh berarti semacam bedak cair, yang berfungsi untuk memperwangi atau mendinginkan tubuh. Makna simbolik adalah agar rumah senantiasa menjadi tempat yang menyenangkan dan menentramkan, mendinginkan hati.

Pada hakikatnya, semua ubo rampe merupakan simbol yang memiliki makna-makna khusus. Hanya saja masyarakat sekarang banyak yang tidak tahu memaknai ubo rampe tersebut, padahal menurut mereka ubo rampe tersebut merupakan manifestasi rasa syukur atau perlambang sutau permohonan kepada Tuhan Yang Maha Esa. .(Giri MC, 2010: 15) Karena itu perwujudan ikhlas permohonan tersebut dibuktikan dengan keikhlasan penderma ketika berbelanja syarat ubo rampe atau pernik-pernik aneka sajen tanpa sedikitpun merasa berat atau terbebani. Belum lagi setelah ubo rampe ini usai didoakan maka ubo rampe 
tersebut wajib dibagi-bagikan atau dimakan bersama-sama. Setidaknya peristiwa ini menggambarkan perwujudan rasa ikhlas untuk bersedekah. Berikut gambar beberapa ubo rampe yang dipergunakan dalam tradisi ini:
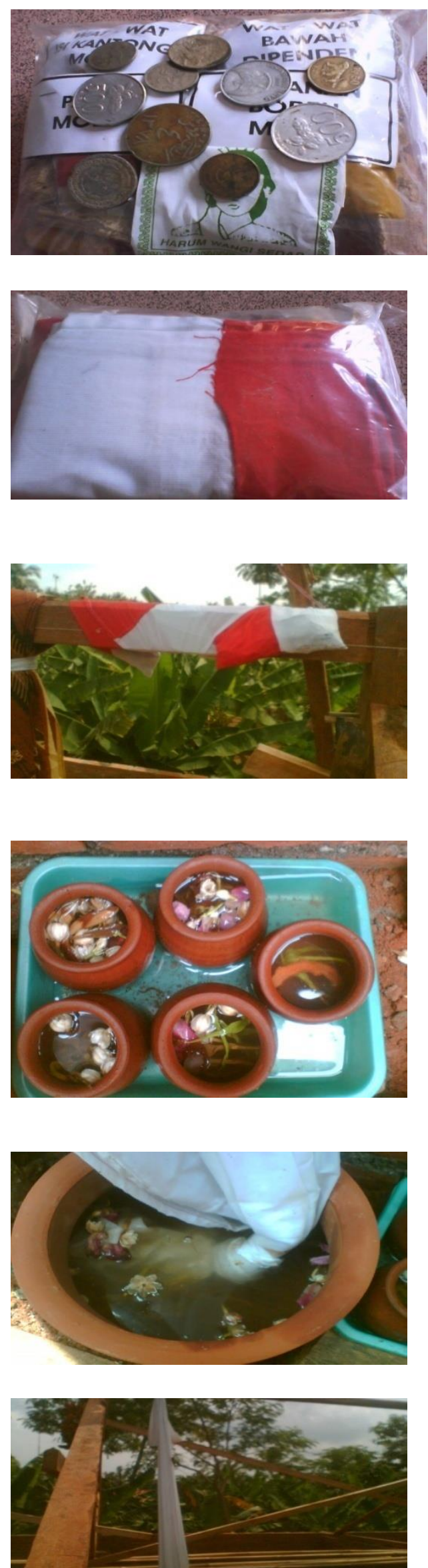

\section{Gambar 1}

Uang recehan, uwat-uwat, dan paku (mas) yang nanti dimasukkan ke dalam Molodimasukkan ke dalam Molo

Gambar 2 dan 3

Bendera merah putih yang akan dibuat kantong Molo dan Molo yang telah jadi dan terpasang

\section{Gambar 4}

Kembang setaman

\section{Gambar 5}

Periuk berisi air, tempat ujung bengking 


\section{Gambar 6}

Bengking atau stagen

Semua ubo rampe yang ada dipasang bersama dan dinaikkan ke atas kayu blandar di atas sebagaimana tampak pada gambar 7,8 dan 9 berikut:
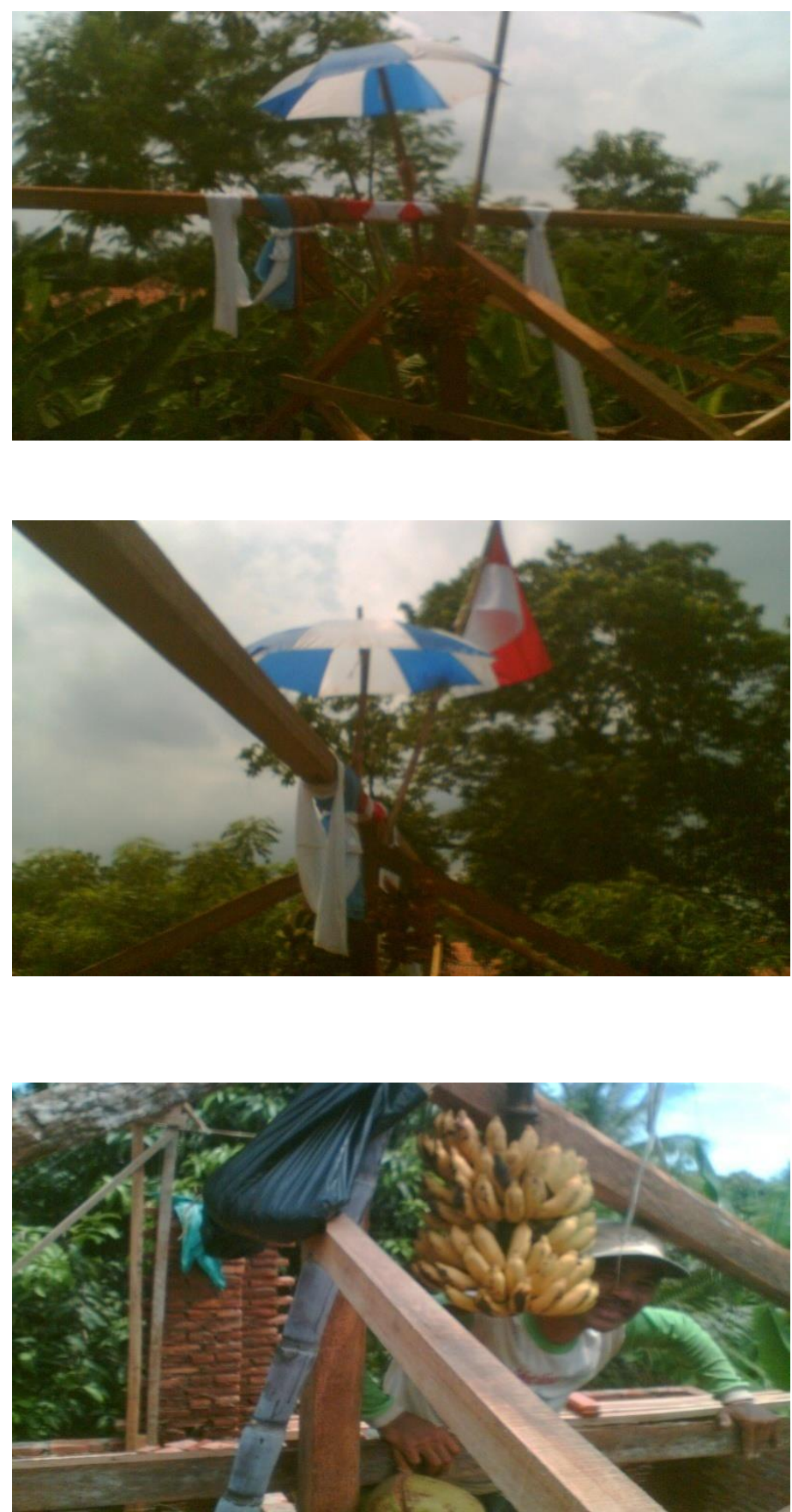

\subsection{Fungsi Sosial}


Turner dalam Sairin mengatakan bahwa kalau seseorang atau suatu masyarakat bergerak dan pindah dari satu status ke status yang lain baik secara vertikal maupun horizontal, maka akan terjadi suatu fase yang disebut sebagai fase transisional. Dalam fase transisi itu, orang atau masyarakat tersebut akan berada dalam keadaan tidak di sini dan tidak di sana (betwixt and between), sehingga secara mentalitas mereka berada dalam suatu keadaan yang disebut Turner dengan istilah Liminalitas. Pada fase ini orang seakan tidak mempunyai norma dan sistem nilai yang jelas (ambigu), tidak di dunia lama yang mulai ditinggalkannya dan tidak pula di dunia baru yang ingin dicapainya. Untuk dapat bertahan dan berpegang teguh pada kehidupan tradisional tidak mungkin lagi karena dianggap tidak cocok dan ketinggalan jaman, tetapi untuk meninggalkannya secara keseluruhan juga tidak mungkin karena model kehidupan baru pun belum jelas dalam sistem gagasan mereka. Dalam keadaan masyarakat cenderung yang sedang berubah (transisi) seperti itu, secara teoritis akan muncul empat kelompok masyarakat (Safri Sairin, 2002: 173, 197) yaitu :

1. Mereka yang berupaya untuk bertahan dalam mengaktualisasikan nilai nilai budaya lama dalam kehidupan mereka.

2. Mereka yang cenderung memungut simbol-simbol budaya masyarakat industri maju sebagai model acuan secara apa adanya. Tanpa sempat lagi untuk mempertimbangkan akan fungsinya dalam kehidupan yang sedangmereka jalani.

3. Mereka yang mampu memadukan dengan serasi kedua gagasan yang berbeda itu secara fungsional dalam kehidupan mereka.

4. Kelompok masyarakat yang cenderung mengambil secara sepotong sepotong unsur-unsur budaya lama dan budaya baru itu secara bersamaan. Namun yang diambil mereka umumnya adalah aspek simbolik materialistik.

Sebagai sebuah tradisi, Munggah Molo menjadi bagian integral dari kehidupan masyarakat Pekalongan, terutama dalam hal pendirian rumah. Secara fungsional, tradisi Munggah Molo dirasakan oleh masyarakat, ia bukan saja bermanfaat bagi setiap anggota masyarakat secara personal, namun terdapat fungsi lain yang sangat urgen dalam kehidupan bermasyarakat yaitu: .

\section{Sebagai Perekat Sosial (Social Integration).}

Sebagai alat integrasi, tradisi Munggah Molo mempunyai karakter yang dapat dipahami sebagai tradisi khas suatu masyarakat karena:

Pertama: tradisi Munggah Molo dapat mengintegrasikan masyarakat tanpa melihat asal usul etnis, baik tionghoa maupun arab. Pada titik ini semua merasa sedang menjalankan warisan leluhur, yaitu Munggah Molo. Orang yang tidak melaksanakan ini merasa ada yang 
kurang karena tidak menjalankan apa yang telah dilakukan oleh para pendahulu. Hal ini menjadi sangat penting sebagai alat integrasi, mengingat bangsa indonesia adalah bangsa yang majemuk. Termasuk di Pekalongan terdapat masyarakat yang berasal dari berbagai etnis, bisa menjadi alat mencegah sikap etnosentrisme.

Kedua: tradisi Munggah Molo dapat mengintegrasikan berbagai status sosial masyarakat dalam kehidupan masyarakat Pekalongan. Ia dapat mempertemukan antar warga masyarakat dalam satu kepentingan seperti membantu orang yang berhajat. Melalui tradisi ini, dapat bertemu antara yang miskin dan yang kaya bersama-sama membantu orang yang membutuhkan, sesuai dengan tingkat kemampuan mereka dan melihat kebutuhan atau kepentingan mereka ke depan. Di samping itu akan menjadikan hilangnya jarak di antara mereka sehingga bisa terjalin komunikasi yang baik.

Ketiga: tradisi Munggah Molo dapat menjadi barometer atau standar tentang tingkat sosial dari warga masyarakat Pekalongan. Munggah Molo menjadi salah satu tradisi, yang dapat dijadikan sebagai alat takar, khususnya dalam mengukur apakah seseorang termasuk warga yang dapat hidup bermasyarakat atau tidak. Biasanya orang yang tidak melaksanakan tradisi ini akan dikatakan sebagai 'wong sing ora umum", orang yang tidak lumrah dalam konotasi negatif, yaitu orang yang tidak bisa bergaul dengan masyarakat. Karena itu masyarakat pekalongan sedapat mungkin pasti melaksanakan tradisi ini, meski dalam pelaksanaannya dengan sederhana, di antaranya karena menghindari adanya efek sosial yang negatif ini. Di samping itu juga bisa menjadi wadah memupuk semangat gotongroyong, kebersamaan yang kian memudar. Dulu bekerja sama, membantu orang lain tanpa upah adalah cermin kerukunan yang berharga, tingkat sosial yang tinggi. Tetapi sekarang, pandangan dan penilaian orang terhadap gotong royong ataupun kerja bakti telah berubah. Sangat sukar mengerahkan tenaga orang untuk bekerja tanpa upah. Sebab kerja tanpa upah dipandang bukan lagi merupakan kerja kemasyarakatan.(Umar Khayam, 1982: 27)

\section{Sebagai Penopang dan penjaga tradisi Budaya.}

Tradisi Munggah Molo merupakan tradisi yang lahir dari masyarakat jawa yang lebih mengedepankan perasaan dan sebagai alat dan modal sosial untuk menyelaraskan kehidupan dan tujuan mulia lainnya seperti kebersamaan, gotong royong, rukun dan saling menghargai antar sesama . Terkadang ini juga menjadi sarana melestarikan nilai-nilai yang bersifat sosial sekaligus keagamaan. Dua hal ini sebenarnya bagaikan dua sisi mata uang yang tidak bisa dipisahkan.Terlebih pada masa sekarang Munggah Molo juga disertai hal-hal yang bersifat 
"keagamaan" seperti pembacaan manaqib syekh Abdul Qadir al-Jailani, shalawatan atau tahlilan. Hal-hal seperti itu menurut masyarakat adalah bagian dari ibadah.

Tradisi Munggah Molo merupakan warisan sosial yang hanya dapat dimiliki oleh warga masyarakat pendukungnya dengan jalan mempelajarinya. Ada cara-cara atau mekanisme tertentu yang bisa dipakai "memaksa' masyarakat memahami tradisi yang penuh dengan nilai-nilai dan norma ini. Ini bisa dilakukan dengan cara formal diajarkan dalam pendidikan atau langsung dengan sosialisasi yaitu melaksanakan tradisi tersebut. Karena itu pelaksanaan tradisi Munggah Molo merupakan alat efektif untuk menjaga sekaligus sosialisasi tradisi agar tidak punah.(Purwadi, 2005: 2)

Sebagai orang jawa, sebenarnya tidak hanya cukup melaksanakan tradisi ini saja tanpa tahu maknanya, karena jika demikian, apa yang dilaksanakan sebenarnya tidak ada maknanya dan pasti lambat laun tradisi ini akan hilang, karena dianggap sesuatu yang ribet dan merepotkan saja. Sebagaimana kata Giri MC, (2010: 14-15) bahwa di antara penyebab orang meninggalkan tradisi yang telah dilakukan secara turun temurun ini justeru karena transfer pewarisan prosesi tradisi atau ritual tidak diikuti dengan penjelasan maksud, tujuan serta simbol-simbol yang terkandung di dalamnya.

\section{Simpulan}

Pertama, bahwa dalam tradisi Munggah Molo yang dilakukan oleh masyarakat Jawa Pekalongan terdapat bentuk-bentuk kebahasaan yang ada didalamnya, baik dalam bentuk kebahasaan dalam bentuk lingustik maupun bahasa-bahasa simbol. Bentuk-bentuk kebahasaan tersebut berupa sejumlah leksikon khusus yang biasa dipakai dalam tradisi Munggah Molo. Begtu juga dalam tradisi Munggah Molo syarat dengan bahasa-bahasa simbol yang mengandung nilai-nilai kehidupan. Ada banyak leksikon serta simbol yang biasa digunakan dalam tradisi Munggah Molo di masyarakat Jawa Pekalongan, diantara adalah Munggah, Molo, blandar, uwat-uwat, bengking, gendero, kembang setaman, gedang sepet, baskom, duit receh, kidung, kelopo, payung, paku emas, pari, juwidah pasar, dan lain sebagainya.

Kedua adalah bahwa simbol-simbol yang terdapat dalam tradisi Munggah Molo mengandung arti serta maksud yang diharapkan. Makna-makna simbolik ini sedikit banyaknya berupa mitos atau kepercayaan masysarakat jawa Pekalongan dalam memahami kehidupan. Hal ini terjadi secata turun temurun dari para nenek moyangnya sekalipun kepercayaan-kepercayaan itu saat ini sudah mulai mengalami pergeseran bahkan perubahan. Ubo rampe seperti halnya uwat-uwat, bengking, duit receh, gedang sepet dan lain sebagainya, 
kesemuanya mempunyai makna simbolik yang mencakup pada nilai-nilai kehidupan yang diyakini. Sebagai contoh; uwat-uwat menunjukan simbol bahwa penghuni rumah itu harus kuat dan bisa panjang umur. Kembang setaman sebagai simbol memancarkan keharuman. Artinya orang atau tamu dan penghuninya merasa betah di rumah. Makna simbolik dari gedang sepet adalah seseorang dalam menjalani hidup harus berani sepet atau prihatin, karena itu semuanya sebenarnya itu semua akan menghasilkan manis. Terdapat juga Ayam Panggang yang dimaksudkan sebagai simbol mensucikan orang yang punya hajat (kebutuhan), dan lain sebagianya.

Ketiga yang dapat ditarik adalah bahwa tradisi Munggah Molo di Pekalongan mempunyai fungsi sosial yang sangat penting terutama di dalam menjalin harmonisasi sosial pada masyarakat Pekalongan. Kerhamonisan ini tidak hanya berlaku untuk masyarakat Jawa (etnis Jawa asli) semata akan tetapi dampak keserasian ini juga dapat dirasakan oleh etnis lain seperti etnis Cina dan Jawa. Hal ini sangat menarik, dikarenakan tradisi Munggah Molo tidak hanya dilakukan oleh masyarakat Jawa Pekalongan saja tetapi juga dilakukan oleh etnis Arab dan Cina yang berada di wilayah Pekalongan.[MU] 


\section{DAFTAR PUSTAKA}

Brian, Morris, Antropologi Agama, Kritik Teori-Teori Agama Kontemporer, Yogyakarta: AK Group, 2003.

Burling, Linguistic and Etnograficc Description, New York: JCM,1973.

Deny Setyaningsih, "Dampak Industri Konveksi terhadap Pergeseran Nilai Kerukunan dalam Masyarakat Jawa", Skripsi, Unnes Semarang, 2006.

Dillistone, F.W. The Power of Symbols, Yogyakarta: Kanisius, 2002.

Fatimah, Nurul, "Peranan Industri Pengolahan Serat Rami Dalam Kehidupan Sosial Ekonomi Masyarakat”. Skripsi. Semarang : Fakultas Ilmu Sosial UNNES, 2005.

Heddy Shry Ahimsa Putra, Strukturalisme Levi-Strauss: Mitos dan Karya Sastra, Yogyakarta: Kepel Press, 2006.

Joyomartono, Mulyono, Perubahan Kebudayaan dan Masyarakat Dalam Pembangunan. Semarang: IKIP Semarang Press, 1990.

Kabupaten Pekalongan dalam Angka 2005

Kesuma, Tri Mastoyo Jati. Pengantar (Metode) Penelitian Bahasa,Yogyakarta: Carasvati Books, 2007.

Khayam, Umar, dkk., Perubahan Nilai-Nilai di Indonesia, Bandung: Alumni, 1982

Koentjaraningrat , Tjelapar: Sebuah Desa di Djawa Tengah Bagian Selatan, dalam masyarakat desa di Indonesia Masa Ini, Jakarta: UI Press, 1984. , Pengantar Ilmu Antropologi. Jakarta: Aksara Baru, 1986 , Kebudayaan, Mentalitas dan Pembangunan. Jakarta: Gramedia, 1974.

Kushartantanti dkk, Pesona Bahasa; Langkah Awal Memahami Linguistik, Jakarta: PT Gramedia Pustaka Utama, 2005.

Levi-Strauss, Structural Anthropology, New York: Casic Books, 1963.

Mangun Suwito, SA, Kamus Bahasa Jawa, Bandung: CV Y Ramawidiya, 2007.

Maryadi, Transformasi Budaya, Surakarta: Muhammadiyah University Press, 2000.

Moleong, J. Lexy, Metodologi Penelitian kualitatif. Bandung: Remaja Rosdakarya, 2001.

Mulder, Neils, Pribadi dan Masyarakat di Jawa, Jakarta: Sinar Harapan, 1996.

P.M., Laksono, Tradisi Dalam Struktur Masyarakat Jawa; Kerajaan dan Pedesaan, Jakarta: Fakultas Sastra Universitas Indonesiam 1984.

Purbatjaraka, Kepustakaan Jawa, Jakarta: Djambatan, 1952.

Purwadi, Upacara tradisional Jawa, Yogyakarta: Pustaka Pelajar, 2005.

Sairin, Safri, Perubahan Sosial masyarakat Indonesia. Perspektif antropologi. Yogyakarta: Pustaka Pelajar, 2002.

Spradley, James P. Metode Etnografi, Yogyakarta: Tiara Wacana, 1997.

Sudaryanto, Metode dan Aneka Teknik Analisis Bahasa, Yogyakarta: Duta Wacana University Press, 1993.

Tim Litbang Kompas, Profil Daerah Kabupaten dan Kota, Jakarta: Kompas, 2003.

Wahyana Giri MC, Sajen dan Ritual Orang Jawa, Yogyakarta: Narasi, 2010.

William A. Foley, Anthropological Linguistics: An Introduction, Oxford: Blackwell Publisher Ltd, 1997.

www.pekalongankab.go.id 
Kholid, warga Pekalongan, wawancara pribadi, 10 Februari 2015

Kiptiyah, warga Pekalongan, wawancara pribadi, 10 Februari 2015

Muhsin, warga Pekalongan, wawancara pribadi, 9 Februari 2015

Mustafa, warga Pekalongan, wawancara pribadi, 20 Januari 2015

Wahidin, warga Pekalongan, wawancara pribadi, 6 Februari 2015

Wahmudi, warga pekalongan, wawancara pribadi, 6 Februari 2015.

Wandi, warga Pekalongan, wawancara pribadi, 15 Februari 2015. 